\title{
C-peptide to Creatinine Ratio Measurement
}

National Cancer Institute

\section{Source}

National Cancer Institute. C-peptide to Creatinine Ratio Measurement. NCI Thesaurus.

Code C150837.

The determination of the ratio of C-peptide compared to creatinine present in a sample.

The measurement may be expressed as a ratio or percentage. 